\title{
Profile of Ability to Produce Fantasy Story Texts of Mataram City Junior High School Students: Aspects of Structure, Language, Characteristics and Coherence
}

\author{
Syaiful Musaddat* \\ Department of Language and Arts \\ Education \\ University of Mataram \\ Mataram, Indonesia \\ syaiful_musaddat@unram.ac.id
}

\author{
M Murahim \\ Department of Language and Arts \\ Education \\ University of Mataram \\ Mataram, Indonesia \\ murahim@unram.ac.id
}

\author{
M. Syahrul Qodri \\ Department of Language and Arts \\ Education \\ University of Mataram \\ Mataram, Indonesia \\ syahrulqodri@unram.ac.id
}

\author{
M Mari'i \\ Department of Language and Arts Education \\ University of Mataram \\ Mataram, Indonesia \\ marii@unram.ac.id
}

\author{
Cedin Atmaja \\ Department of Language and Arts Education \\ University of Mataram \\ Mataram, Indonesia \\ cedinatmaja@unram.ac.id
}

\begin{abstract}
This study aims to describe the profile of the ability to produce fantasy story texts for junior high school students in Mataram city. The aspects studied include structure, linguistic rules, characteristics, and coherence. The data was collected through the document review method. The source of data is the text of fantasy stories made by junior high school students in Mataram city. In this case, the sample was taken from four schools, namely two city center schools (junior high school 2 and 15 Mataram) and two suburban schools (junior high school 3 and 8 Mataram). The data analysis is conducted by following the principles in qualitative research, namely the data reduction stage, data presentation or organization, and data verification or interpretation. Based on the results and discussion, it can be described the profile of the ability of junior high school students in Mataram city in making fantasy story texts, namely as follows. (1) In the aspect of the fantasy story text structure, the ability of junior high school students in Mataram city is in the quite capable category with an average score of 78.125 ; (2) In the aspect of linguistic rules of fantasy story text, the ability of junior high school students in Mataram city is in the capable category with the average score of 83.125 ; (3) In the aspect of the characteristics of the fantasy story text, the ability of junior high school students in Mataram city is in the quite capable category with average score of 72.50; and (4) In the aspect of the coherence of the fantasy story text, the ability of junior high school students in Mataram city is in the capable category with average score of 82.50 . In general, the profile of the ability of junior high school students in Mataram city in making fantasy story texts is in the capable category with average score of 79.06. However, in some samples there are also students whose abilities in the very capable, quite capable, and even incapable categories. It is suggested for teachers to be more intense in guiding their students, including providing special guidance for students who are still in the sufficient and incapable category.
\end{abstract}

Keywords: profile, ability, making text, fantasy story, structure, linguistic, characteristics, and coherence.

\section{INTRODUCTION}

In 2018 and 2019, a study was conducted on the quality of planning and implementation of text-based learning as a characteristic of K-13 in senior high schools in West Lombok Regency [1]; [2]. Through this research, it is known that the competence of Indonesian language teachers (especially Alumni of PBSI FKIP Unram) in West Lombok regency in designing text-based learning is still not optimal. Furthermore, the findings of this study indicate that not a single PBSI FKIP Unram Alumni (who was the research sample) has produced text-based learning lesson plans that are in accordance with the demands of K-13. The developed of lesson plans have not yet described the text-based learning stages that K-13 wants. This is in line with the results of community service activities that conducted by Intian, et al., [3] and Dharma research. [4].

With the improvement of the curriculum in its various components, the implementation of $\mathrm{K}-13$ has become a concern. For this, a comprehensive study is needed related to the implementation of K-13, namely a study of the design or lesson plans, implementation of learning, and evaluation of learning. This is important to be able to provide a comprehensive description or a full profile about the implementation of K-13. Through this study, various models can be developed in implementing K-13. For example, the lesson plan model, the learning implementation model, and the K-13 learning evaluation model. This study is also very important to be used as input for institutions (FKIP Unram), especially the PBSI Study Program in order to develop the quality of the alumni, both the quality of prospective alumni (inside) and the quality of alumni (outside). It will also be used as input in order to optimize the implementation of $\mathrm{K}$ 13.

In 2020, a study was conducted through research on the feasibility of learning the scientific approach profile and its effect on students' ability to create a text. One part of the results of the study is a portrait of students' abilities in 
creating the text. Therefore, this study discusses the profile of the ability to create fantasy text for junior high school students in Mataram city. The aspects studied include structure, linguistic rules, characteristics, and coherence.

In the context of learning, the scientific method can be defined as a learning model that uses scientific principles, in the form of data collection and analysis activities through observation, questioning, experiments, processing information or data, and communicating [5]. According to Karar and Yenice [6], the scientific approach is a learning process designed so that students actively construct concepts, laws or principles through observing, formulating problems, formulating hypotheses, collecting data, analyzing data, drawing conclusions, and communicating the results. Hosman [7] and Rusman [8], state that the scientific method is a learning approach that provides broad opportunities for students to explore and elaborate through observing, questioning, experimenting, and reporting activities. Thus, it can be concluded that the scientific method is a learning activity through observation, questioning, experimentation, processing information or data, and communicating. Therefore, the steps of a scientific approach in the learning process include observing, questioning, trying, processing and analyzing data, reasoning, concluding, communicating, and creating and forming networks [7];

The scientific approach in Indonesian language learning must be combined with text-based learning. Text-based Indonesian learning in the 2013 curriculum is based on several principles. These principles are: (a) language should be viewed as a text, not just a collection of words or linguistic rules; (b) the use of language is a process of selecting linguistic forms to express meaning; (c) language is functional, that is, the use of language can never be separated from the context because the form of the language used reflects the ideas, attitudes, values and ideology from the users; and (d) language is a medium of forming human thinking abilities, and the way of thinking is realized through text structures [9].

Text-based learning is the learning that makes text as the basis, principle, base, and reference for learning [10]. The learning method in text-based learning is carried out in three stages that conducted in cycles, namely: (1) introduction to context and modeling, (2) development of text together, and (3) independent text development [9]; [11]. In this case, textbased learning is taught through three categories of learning activities, namely: context recognition and modeling, development of text together, and independent text development [12].

According to Kosasih [13] and Mahsun [11], genre as a type of text can be classified into factual and fictional genres. Factual genre is a type of text that is created based on actual events, conditions, or circumstances in the environment. Fiction genre is a type of text that is created based on imagination, not on actual reality. Factual genres include: reports, descriptions, procedures, recounts, explanations, expositions, and discussions. On the other hand, the fiction genre includes: recounts, anecdotes, story / narrative, and exemplum.

Fantasy story text is classified as types of literary genre text, part of storytelling and narrative texts [11]. Fantasy story text is one of the essays that belong to the genre text in the form of fantasy or imagination. In the 2013 curriculum, this type of text is one type of text that must be mastered by students. This text was studied in junior high school. The function of fantasy story text is to support the development of student creativity as well as a medium of entertaining themselves.

Fantasy story text has four structures, namely orientation, complications, resolution, and coda [13]; [11]. Orientation (opening) is an introduction to the theme, characterizations, and a little storyline. Complication is the part that shows the problem to the climax of the problem. Resolution is the part of solving the problem or conflict that occurs. Meanwhile, coda (closing) is the ending part of the story. Endings can be divided into 2, namely happy ending and bad ending.

In addition to structure, fantasy story texts also have their own linguistic rules and characteristics. The linguistic rules of the fantasy story text are in the form of the use of: (1) the point of view of characterizations such as me, them, us, and people's names; (2) the words of personification (parable); (3) marker conjunctions for chronological sequences; and (4) expressions or direct sentences to add sense to the content of the story. The characteristics of the fantasy story text are: (a) has oddities that are beyond reason such as witchcraft, magical creatures, or something mysterious; (b) there is a use of time and space; (c) the main characters are generally made to have their own uniqueness, such as having super powers that serve to save the world; and (d) using fantasy/imagination [13]; [12]; and [11]. Another thing that is an integral part of all texts including fantasy story texts is the aspect of coherence. This aspect is related to the cohesiveness of all text components, either explicitly or implicitly.

\section{METHODS}

Methodologically, this research was conducted in three stages, namely (1) pre-research stage or preparation of proposals, preparation of research instruments, and preparation of research tools and materials; (2) the research stage which includes data collection and analysis; and (3) the post-research stage which includes the preparation of a research report. The data collection through document review method. The sources of data from fantasy story texts that created by junior high school students in Mataram city. The sample was selected by using a random sampling technique to cluster the city center and suburban schools. Four schools were assigned as samples, namely junior high school 2 (P2) and junior high school 15 (P15) Mataram city representing city center schools and junior high school 3 (P3) and junior high school 8 (P8) Mataram city representing suburban schools. The data analysis was conducted by following the principles of qualitative research, namely the stages of data reduction, data presentation or organization, and data verification or interpretation. Meanwhile, the method of presenting the data will be formal and informal methods [14].

\section{RESULTS AND DISCUSSION}

This part presents the results of research and discussion related to the profile of the ability to create fantasy text for junior high school students in Mataram city. The presentation will be adjusted with the formulation of the 
problems discussed, namely the ability to create fantasy story texts from the following aspects: (1) structure, (2) linguistic rules; (3) characteristics, (4) and coherence.

\section{The Ability to Create Fantasy Story Texts for Junior High School Students in Mataram City from the Structural Aspect}

The components of ability that are measured in the structural aspects of the fantasy story text are orientation, complication, resolution, and coda [13]; and [11]. The measure of the ability category used is based on Mahsun's opinion [11], namely the scores are 90-100 for very capable category, the scores are 79-89 for capable category, 66-78 score for quite capable category, 40-65 for underprivileged category, and less than 40 for incapable category.

The description of the ability to create fantasy story text for junior high school students in Mataram city from the structural aspect can be seen in table I below.

TABLE I. THE DESCRIPTION OF THE ABILITY TO CREATE FANTASY TEXT FOR JUNIOR HIGH SCHOOL STUDENTS IN MATARAM CITY FROM THE STRUCTURAL ASPECT

\begin{tabular}{|c|c|c|}
\hline No & School Name & Structure \\
\hline 1 & P3 & 13.5 \\
\hline 2 & P8 & 15.5 \\
\hline 3 & P15 & 15 \\
\hline 4 & P2 & 18.5 \\
\hline & Average & 15.625 \\
\hline & Average Acquisition & 62.5 \\
\hline & Average Score & 78.125 \\
\hline & Average Category & Quite Capable \\
\hline
\end{tabular}

Based on table I, it is known that the overall ability to create fantasy story text for junior high school students in Mataram city from the structural aspect is in the quite capable category. The average score was 62.5 and the average conversion score was 78.125. The average score is in the quite capable category, which is between 66 and 78 .

In general, in creating or using fantasy story text structures, a quite number of students did well. At least 15 samples $(37.5 \%)$ can produce the text structure of fantasy stories well. For example, on data 3002, 3004, 8001 until 8004, 15007, 15008, 15010, 2001, 2002, 2003, 2005, and 2008, students have used the four text structures of fantasy stories, namely orientation, complications, resolution, and coda. In others, it was found that students had used two or three text structures for fantasy stories. However, there are also samples that use only one structure. There are at least four samples $(10 \%)$ that only use one fantasy story text structure. The rest of samples (8 samples) used two structures and 13 samples used 3 text structures.

For the structural aspect, in general the junior high school students in Mataram city are mostly capable, some are even very capable in producing structures in the form of orientation, complications, resolution, and coda. From the total of 40 samples, only three students created one structure and six students created two structures. The rest have created three or four structures.

2. The Ability to Create Fantasy Story Texts for Junior High School Students in Mataram City from the

\section{Linguistic Rules Aspect}

The components of the ability that are measured in the aspects of the linguistic rules of the fantasy story text are point of view, characterization, personification, conjunction, and direct sentences. [13]; and [11]. The description of the ability to create fantasy story text for junior high school students in Mataram city from the aspect of linguistic rules can be seen in table II below.

TABLE II. THE DESCRIPTION OF THE ABILITY TO CREATE FANTASY STORY TEXTS FOR JUNIOR HIGH SCHOOL STUDENTS IN MATARAM CITY FROM THE ASPECT OF LINGUISTIC RULES

\begin{tabular}{|c|c|c|}
\hline No & School Name & Language \\
\hline 1 & P3 & 14.5 \\
\hline 2 & P8 & 16 \\
\hline 3 & P15 & 18 \\
\hline 4 & P2 & 18 \\
\hline & Average & 16.625 \\
\hline & Average Acquisition & 66.5 \\
\hline & Average Score & 83.125 \\
\hline & Average Category & Capable \\
\hline
\end{tabular}

Based on table II, it is known that the overall ability to create fantasy story text for junior high school students in Mataram city from the aspect of linguistic rules is in the capable category. The average score was 66.5 and the average conversion score was 83.125 . The average score is in the capable category, which is between 79 and 89 .

From all the samples, only 4 students (10\%) were still less able to use linguistic rules. The data 3005, illustrates that students have used the four linguistic rules of fantasy story text, namely the point of view of characterization, personification, conjunctions, and direct sentences.

For the aspect of linguistic rules, in general junior high school students in Mataram city are mostly capable and very capable of using linguistic rules in the form of characterization point of view, personification, conjunction, and direct sentence. From the total of 40 samples, only four students used two linguistic elements. The rest have created three or four linguistic elements.

3. The Ability to Create Fantasy Story Texts for Junior High School Students in Mataram City from the Characteristic Aspect

The components of ability that measured in the characteristic aspects of fantasy story text are oddity, space/time, uniqueness, and imagination [13]; and [11]. The description of the ability to create fantasy text for junior high school students in Mataram city from the characteristic aspects can be seen in table 3 below.

TABLE III. THE DESCRIPTION OF THE ABILITY TO CREATE FANTASY STORY TEXTS FOR JUNIOR HIGH SCHOOL STUDENTS IN MATARAM CITY FROM THE CHARACTERISTIC ASPECT

\begin{tabular}{|c|c|c|}
\hline No & School Name & Characteristic \\
\hline 1 & P3 & 12.5 \\
\hline 2 & P8 & 14.5 \\
\hline 3 & P15 & 15 \\
\hline 4 & P2 & 16 \\
\hline & Average & 14.5 \\
\hline & Average Acquisition & 58 \\
\hline & Average Score & 72.5 \\
\hline & Average Category & Quite Capable \\
\hline
\end{tabular}

Based on table III, it is known that the overall ability to create fantasy story text for junior high school students in Mataram city from the characteristic aspect is in the quite 
capable category. The average score was 58 and the average conversion score was 72.5. The average score is in the quite capable category, which is between 66 and 78 .

In this aspect, almost all samples have been able to use the characteristics of the fantasy story text completely and well. Only 3 samples were recorded using only one characteristic. This also occurs in data 3001, 3005, 3009, $8001,8009,15001,15005,15009,2004,2008$, and 2009 illustrating that students have used the four characteristics of fantasy story texts. Characteristics consisting of oddities, space / time, uniqueness, and delusion can be used or made well. However, in some data, namely 3007 and 3008, only use one characteristic of the fantasy story text, namely space/time.

For the characteristic aspect, in general, junior high school students in Mataram city are mostly capable and very capable of creating characteristics in the form of oddities, space / time, uniqueness, and delusion. From the total of 40 samples, only three students are classified as not capable because they created one characteristic. The rest have created two or three characteristic elements.

\section{The Ability to Create Fantasy Story Texts for Junior High School Students in Mataram City from the Coherence Aspect}

The ability component that is measured in the coherence aspect of the fantasy story text is the integration between parts of the fantasy story text, both explicitly and implicitly [14]; dan [12]. The description of the ability to create fantasy story texts for junior high school students in Mataram city from the aspect of coherence can be seen in table IV below.

TABLE IV. THE DESCRIPTION OF THE ABILITY TO CREATE FANTASY STORY TEXTS FOR JUNIOR HIGH SCHOOL STUDENTS IN MATARAM CITY FROM THE ASPECT OF COHERENCE

\begin{tabular}{|c|c|c|}
\hline No & School Name & Coherence \\
\hline 1 & P3 & 15.5 \\
\hline 2 & P8 & 16.5 \\
\hline 3 & P15 & 17.5 \\
\hline 4 & P2 & 16.5 \\
\hline & Average & 16.5 \\
\hline & Average Acquisition & 66 \\
\hline & Average Score & 82.5 \\
\hline & Average Category & Capable \\
\hline
\end{tabular}

Based on table IV, it is known that the overall ability to create fantasy story text for junior high school students in Mataram city from the coherence aspect is in the capable category. The average score was 66 and the average conversion score was 82.5. The average score is in the capable category, which is between 79 and 89 .

There are at least 18 samples $(45 \%)$ who have shown the ability to use coherence very well. There is only one sample that uses coherence poorly, namely code 3004. For example in data 3001 , the first paragraphs to the fifth paragraphs show coherence that is related between one paragraph and another. This is not the case with data code 3004, in the first paragraph to the second paragraph indicates that the text of the fantasy story is incomplete or has no coherence between one paragraph and another.
For the coherence aspect, in general junior high school students in Mataram city were mostly capable and quite capable of using coherence or integration. From the total of 40 samples, only one student is classified as incapable because it does not use strong coherence. The rest have used coherence in most or some parts of the text created.

In general, the ability to create fantasy story text for junior high school students in Mataram city from the aspects of structure, linguistic rules, characteristics, and coherence is in the capable category. The average score was 63.25 and the average conversion score was 79.0625. The average score is in the capable category, which is between 79 and 89. However, in several samples from several schools there were also students whose abilities in creating fantasy story texts were in the very capable category, namely two students from junior high school 8 Mataram (code 8001 and 8009), three students from junior high school 15 Mataram (code 15001, 15009), and 15010), and 3 students from junior high school 2 Mataram (code 2001, 2002, and 2005). In addition, there are also samples categorized as underprivileged, namely two students each from junior high school 3 and junior high school 8 Mataram (code 3003, 3010, 8007, and 8010).

\section{CONCLUSION}

Based on the description of the results and discussion above, it can be concluded that the ability of junior high school students in Mataram city in creating fantasy story texts is in the capable category with an average score of 79.06. However, in some samples there are also students whose abilities are in the very capable, quite capable, and even incapable categories. The students' abilities in each aspect are: (1) In the aspect of structure of the fantasy story text, the ability of junior high school students in Mataram city is in the quite capable category with an average score of 78.125; (2) In the aspect of linguistic rules of fantasy story text, the ability of junior high school students in Mataram city is in the capable category with an average score of 83.125; (3) In the aspect of the characteristics of the fantasy story text, the ability of junior high school students in Mataram city is in the quite capable category with an average score of 72.50; and (4) In the aspect of coherence of fantasy story text, the ability of junior high school students in Mataram city is in the capable category with an average score of 82.50. Therefore, it is suggested for teachers to be more intense in guiding their students, including providing special guidance for students who are still in the sufficient and incapable category.

\section{ACKNOWLEDGMENT}

Thanks are conveyed to the University of Mataram as the provider of funding assistance for this research. The funding for this research was through the DIPA BLU (PNBP) source of the University of Mataram through the Research Implementation Agreement Letter Number: 2596 / UN18.L1 / PP / 2020. 


\section{REFERENCES}

[1] S. dkk. Musaddat, "Pelatihan Pengembangan Materi Ajar Berbasis Teks Bagi Guru-guru Bahasa Indonesia Aluni PBSI FKIP Unram di Kabupaten Lombok Barat," J. Pendidik. dan Pengabdi. Masy., vol. 1, no. 2, pp. 321-326, 2018.

[2] S. dkk. Musaddat, "Pemetaan Kompetensi Guru Bahasa Indonesia PBSI FKIP Unram dalam Merancang dan Melaksanakan Pembelajaran Berbasis Teks," J. Mabasindo, vol. 3, no. 1, pp. 136148, 2019.

[3] S. R. H. dkk. Intiana, "Pelatihan Pengembangan Materi Ajar Bagi Guru-guru Bahasa dan Sastra Indonesia di Kabupaten Lombok Utara," J. Pendidik. dan Pengabdi. Masy., vol. 1, no. 1, pp. 165-173, 2018 .

[4] P. S. V dkk. Dharma, "Implementasi Pembelajaran Bahasa Indonesia Berbasis Teks di SMA Negeri 1 Bengkulu Tengah Kelas XI,” J. Ilm. Korpus, vol. 3, no. 1, pp. 66-74, 2019.

[5] Kemendikbud RI, Iplementasi Kurikulum 2013. Jakarta: Kemendikbud, 2014
[6] N. Karar, E. E. dan Yenice, "The investigation of scientific process skill level of elementary education 8th grade students in view of demographic features," in Social and Behavioral Sciences, 2012.

[7] M. Hosnan, Pendekatan Saintifik dan Kontekstual dalam Pembelajaran Abad 21. Bogor: Ghalia Indonesia, 2014.

[8] Rusman, Pemebelajaran Tematik Terpadu. Jakarta: Raja Grafindo Persada, 2015

[9] Depdikbud, Bahasa Indonesia SMA/MA Kelas XII. Jakarta: Depdikbud, 2017.

[10] Sufanti, "Pembelajaran Bahasa Indonesia Berbasis Teks," www.publikasiilmiah. ums.ac.id. 2017.

[11] Mahsun, Pembelajaran Bahasa Indonesia Berbasis Teks (Edisi Kedua). Jakarta: Rajawali Press, 2018.

[12] Isodarus P. Baryadi., "Pembelajaran bahasa Indonesia Berbasis Teks," Kebud. Sint., vol. 11, no. 1, pp. 1-11, 2017.

[13] E. Kosasih, Jenis-jenis Teks dalam Mata Pelajaran Bahasa Indonesia SMA/MA/SMK. Bandung: Yrama Widya, 2014.

[14] Mahsun, Metode Penelitian Bahasa. Depok: PT Raja Grafindo Persada, 2017 